\title{
Interactions between Free Cash Flow, Debt Policy and Structure of Governance: Three Stage Least Square Simultaneous Model Approach
}

\author{
BEN MOUSSA Fatma \\ Ecole Supérieure de Commerce de Tunis, Campus Universitaire de La Manouba \\ B.P. 2010, La Manouba, Tunisie \\ Tel: 216-22-983-095 E-mail: bmoussa_fatma@yahoo.ca \\ Jameleddine Chichti \\ Ecole Supérieure de Commerce de Tunis, Campus Universitaire de La Manouba \\ B.P. 2010, La Manouba, Tunisie
}

Received: May 17, 2011 Accepted: April 18, 2011 doi:10.5296/jmr.v3i2.614

\begin{abstract}
This research tests the efficiency of the ownership structure and the debt policy as mechanism of resolution of agency conflicts between shareholders and managers due to the problem of overinvestment, in the limitation of the problem of the free cash flow. By estimating three stage least square simultaneous model and on the basis of a sample of 35 non financial Tunisian listed companies selected for the period 1999-2008, our results are in favor of the theory of free cash flows of Jensen (1986) that stipulates that the debt policy represents the principal governance mechanism that can limit the risk of free cash flow. Also, it is found that managerial ownership lowers the level of agency costs of free cash flow. However, the ownership concentration increases the risk of the free cash flow.
\end{abstract}

Keywords: Corporate governance, Free cash flow, Debt policy, Ownership structure 


\section{Introduction}

The debate on the convergence-of-interest hypothesis relief of the agency theory (Fama and Miller 1972, Jensen and Meckling 1976) as well as of the signaling theory. The main concerned actors are managers, shareholders and creditors. The basic idea of agency theory is that every agent looks for the maximization of his self interest, from where the apparition of conflicts (Ross, 1977). In these conditions the idea that the financial markets are perfected is rejected. Indeed, these will be determined by asymmetries of information and conflicts of interest.

Several works tempted to estimate agency costs and to test their effect on the cost of capital and also on the firm value. Moreover, an abundant literature is interested in the possible relations between the choice of the level of leverage and agency problem. Two main cases have been exposed. First, debt may reduce agency conflicts resulting from opportunistic behavior of managers. We essentially mention the overinvestment problem (Jensen, 1986). Secondly, the debt aggravates shareholder-creditor agency conflicts. The most studied examples are the asset substitution problem, the problem of transferring wealth from the firm's bondholders to the stockholders and the under investment problem (Smith and Warner (1979), Jensen and Meckling (1976) and Myers (1977)).

In this study we are going to define the role of debt and ownership structure like control's mechanism of the manager's behavior for the firms generating free cash flows.

The concept of free cash flow has been introduced by Jensen (1986), it is cash flow in excess of that required to fund all projects that have positive net present values. The problem is how to encourage managers to disgorge the cash rather than investing it at below the cost of capital or wasting it on organization inefficiencies. Therefore, the affectation of the free cash flow is to the core of the problematic of agency relations.

Indeed, the distribution of this abundant free cash flow appears not constraint by the engagement to use them in the profitable investments, nor by the one to contribute them to operating expenses or to the repayment of the debt. From where the temptation for managers to affect these free cash flow to non profit investments or to destine them to other finalities as the inefficient restructuring plans or the increase of the size of the firm in the only objective to increase their remuneration (Dorff, 2007).

In the context of the agency theory, leverage is considered like an efficient solution to conflicts of interests that can appear between shareholders and managers, contrary to the thesis of Modigliani and Miller (1958), where the capital structure is associated solely to a model of cash - flows, his importance is related to the capacity of creditors to exercise the control.

Thus in case of debt issuing the manager is obliged to face remittances of annuities (Jensen and Meckling (1976), to stop the current operations of the firm and to opt for its liquidation 
(Harris and Raviv (1990)), to be more competitive (Grossman and Hart (1982)) and to limit his discretionary behavior on free cash flow (Jensen (1986), Stulz (1990) and Pindado and De La Torre (2005)).

Also, the development of the relative theory to the corporate governance came to specify other mechanism in order to control managers and to reduce these conflicts. Among these control mechanisms we distinguish the ownership structure. Indeed, the composition of the shareholding of a firm as well as its degree of dispersion influences its strategic and financial orientations. In this case, several authors (Leland and Pyle 1977, Hermalin and Weisbach, 1991,; Himmelberg and al., 1999) consider managerial ownership as evident solution to agency conflicts that permits to align interests of managers on those of shareholders.

Also, the majority of studies related to the effect of ownership concentration confirm the hypothesis of their positive role in the corporate governance. Berle and Means (1932) affirm that a diffuse ownership structure decreases the relationship between the ownership and the control and minimize, therefore, the role of value maximization. To this effect, Jensen and Meckling (1976) affirm that agency costs decrease with the ownership since the ownership change lead to the alignment with interests of managers and shareholders.

Besides, theories on the corporate governance developed in parallel with the financial market development and the rise in power of the institutional investors and numerous reforms have been take place in many countries in order to reinforce the power of shareholders. The institutional investors play an important role in these transformations while requiring new norms favorable to shareholders andwhileexercising an important pressure on managers (Pound and Millar, 1999).

This research intends to test the efficiency of the ownership structure and the debt policy as mechanism of resolution of agency conflicts between shareholders and managers due to the problem of overinvestment, in the limitation of the problem of the free cash flow. So we estimate three stage least square simultaneous model. For the financial policy we are going to test the role of the long term debt in the reduction of investments in excess in firms that have strong agency problems. For the ownership structure we take account of the managerial ownership, the institutional ownership and the ownership concentration.

Tests using a sample of 206 observations for 35 non financial Tunisian listed firms from 1999 to 2008 period indicate that the debt policy represents the principal governance mechanism which can limit the level of free cash flow. However, the ownership concentration and managerial ownership increase the risk of the free cash flow. Finally, the level of the free cash flow is not affected by the institutional ownership.

The rest of the paper is organized as follows. Section 2 reviews the previous theoretical and empirical research. Section 3 describes the empirical framework. The empirical results are presented in Section 4 and Section 5 concludes.

\section{Literature Review and hypotheses}

2.1 Debt policy and agency costs of free cash flow 
The role of debt monitoring in reducing the agency costs of free cash flow is well emphasized in the theoretical and empirical literature.

Jensen [1986, page 323] defines the free cash flow, as the "cash flow in excess of that required to fun all projects that have positive NPV". He says that managers may use free cash flow to invest in negative NPV projects rather than return the free cash flow to the shareholders, for example as dividends. This problem is especially bad in firms who are mature and with low growth opportunities, as they have low profitable investments. However, by increasing debt with its required interest payments, managers are "bonding their promise to pay out future cash flows". Jensen indicates that firms with excess cash flows and low growth opportunities will use more debt financing for monitoring purposes. Stulz (1990) also suggested positive relation between leverage and free cash flow. But their theories find no support from empirical research of Chaplinsky and Niehaus (1990).

Also, Hart and Moore (1995) suggest that the debt doesn't resolve the overinvestment problem by the reduction of the free cash flow but rather it is its priority statute that limits the external amount can be collected by the firm.

Empirically, Lang and al. (1996) find a negative relationship between the leverage and the growth opportunities in firms with low growth opportunities in accordance with the free cash flow theory and find that changes in free cash flow lead to positive changes in leverage in the 142 American listed firms from 1970 to1989.

Gul and Jaggi (1999) develop a composite IOS measure by conducting a common factor analysis on six growth variables in order to classify firms with growth opportunities. The authors use data from 1989 to 1993 to non-regulated industrial firms. Results indicate that the debt has a positive effect on free cash flow firms with low growth opportunities in terms of the bottom quartile of IOS.

Vilasuso and Minkler (2001) develop a dynamic model that incorporates the issues of agency cost and asset specificity. Results based on an unbalanced panel of 28 publicly-held firms show that these two factors are significant determinants of the optimal capital structure of firms. Moreover, results show that agency costs increase with degree of assets specificity.

De Jong and van Dijk (2007) empirically examine the determinants of leverage and agency problems, and they test the relations between leverage and four agency problems i.e. direct wealth transfer, asset substitution, underinvestment and overinvestment. Based on a sample of Dutch firms from 1992 to 1997, the results prove that the trade-off between tax advantages and bankruptcy costs determines leverage. Moreover, free cash flow and corporate-governance characteristics appear to be determinants of overinvestment. Despite findings that agency problems are present, there is no evidence for any relationship between agency problems and leverage.

$\mathrm{Li}$ and cui (2003) test the effect of capital structure on agency costs in 211 non-financial Chinese listed firms for the period from 1999 to 2001. Based on a system of simultaneous equations, results prove that firms with high debt to asset ratio have high ratio of annual sales to total assets and high ratio of return-on-equity. In this case, creditors are more concerned 
about the payment of interest and of principal and will have incentives to monitor the firm. Consequently, a capital structure with high debt decreases agency costs. Results also show a Positive relationship between ownership concentration and the return-on-equity ratio. This is because the blockholders have a strong interest in firm performance and therefore a high capability to monitor manager in order to reduce agency costs.

Wu (2004), using 833 observations of listed Japanese firms for the period 1992-2000 tests the disciplinary role of ownership structure in corporate capital structure policy. Estimating OLS regression with leverage ratio as the dependent variable and several independents variables which are ownership structure, free cash flow, and growth opportunities, the results confirm that the leverage has a positive effect on free cash flow greater for firms with low growth opportunities than firms with high growth opportunities.

Zhang and Li (2008) employ multivariate tests and univariate tests to analyze the hypothesis which suggests that increase of leverage may reduce agency costs. Based on a sample of 323 UK companies, the results confirm that the increase of leverage does reduce agency costs. Nevertheless, when the leverage is sufficiently high, the effect additional increase in leverage has a positive and non significant effect on agency costs. Finally, no significant evidence is found when testing whether the effect of leverage on agency costs becomes stronger when the differences of leverages of firms at different leveraged stages getting larger.

Nekhili and al (2009) test the capacity of governance mechanisms, in the limitation of the problem of the free cash flow in case of French firms. By estimating three stage least square simultaneous model, results prove that distribution of dividends - rather than debt level - that leads to reduction of free cash flow risk.

Recently, D'Mello and Miranda (2010) present a direct test of the overinvestment control hypothesis that states that long-term debt influences the degree to which firms overinvest. They do so by examining the pattern of overinvestment in cash and capital expenditure around new debt issues by unlevered firms. Based on a sample of 366 debt issues between the year 1968 and the year 2001 by firms that have been unlevered for at least three years, the results confirm that issuing debt leads to a reduction of overinvestment. Also, this relation is more significant for firms with poor investment opportunities confirming that debt plays an important role in reducing excess investments in firms that have the highest agency problems.

Agostinho and Prudencio (2010) analyze the capacity of the capital structure policy, the dividend policy, the board and the ownership structure and the practices of social responsibility in the limitation of the free cash flow risk. Using a sample of 298 firms of the NYSE Euronext of the year 2007, the results show that corporate governance mechanisms limit the arbitrariness of the management. In particular, the results confirm the role of leverage in reducing agency costs of free cash flow

Based on these theoretical and empirical works, the following hypotheses apply:

Hypothesis (a): Free cash flow level will be lower at higher levels of debt

Hypothesis $_{1}(b)$ :Leverage is positively related to free cash flow in the firms with low growth opportunities and generating free cash flows. 


\subsection{Ownership structure and agency costs of free cash flow}

The literature provides mixed guidance on the role of ownership structure as a corporate governance mechanism. The ownership concentration, the managerial ownership and the institutional ownership are three attributes that characterize the ownership structure of a firm.

Theoretically, for a firm whose capital is much dispersed, a minority shareholder won't have the incitement, nor the necessary funds to exercise a control on managers. While, for a shareholder possessing an important part in the capital, he will grant more interest to the control of managers. This can be exercised by voting rights that he possesses, either by resources that he can use to supervise managerial actions, and either by the influence that he can exercise on the minority shareholders in order to sustain him in case of disagreement with managerial team.

Jensen and Meckling (1976) affirm that large shareholders are more motivated and have stronger power to guarantee shareholder value maximization, by aligning the interest of managers and shareholders and therefore reduce agency costs.

Zeckhauser and Pound (1990) test whether presence of large shareholders is related to systematic differences in expected earnings growth, dividend payout ratios and leverage ratios. Based on a sample of firms from 22 industries, results show that in 11 industries with a relatively open information structure, large shareholders are associated with significantly higher expected earnings growth rates.

More recent works suggest the benefits of large shareholders in a different context.

Pindado and De La Torre (2005) examine the effect of ownership structure on debt policy on the basis of a sample of 135 Spanish companies from 1990 to 1999. Results show that ownership concentration enhances debt financing in presence of free cash flow problem, even though debt is less used when there is problem of expropriation of minority shareholders by controlling owners. Furthermore, they provide some results about the interaction between insider ownership and ownership concentration. Results show that ownership concentration does not change the relationship between managerial ownership and debt because when entrenched managers are in control, the monitoring role of outside owners become ineffective. Even though, the additional debt promoted by outside shareholders increase when managers are entrenched. So, the relationship between ownership concentration and debt is affected by managerial ownership.

Al-Deehani and Al-Saad (2007) test the impact of the ownership structure on the capital structure of the firms listed in the Kuwait Stock Exchange. Empirical results show a positive relationship between the amount of debt and the level of control rights relative to the level of cash flow rights. Moreover, findings point out a positive relationship between the level of debt and the existence of a manger from a controlling family. Finally, a third positive relationship between the amount of debt and the amount of controlling rights, and cash flow rights and a family concentrated ownership has also been found.

Driffield et al (2007) empirically examine the effects of ownership structure on capital 
structure and firm value among listed non-financial companies in Indonesia, Korea, Malaysia and Thailand. Results obtained from 3SLS model confirm that ownership concentration have significantly positive effects on leverage and firm value. Moreover, results show that ownership concentration tends to minimize agency costs for all groups of firms.

Syriopoulos et al. (2007) tend to show how different ownership structures may influence the allocation of firms' resources and investigate the impact of debt and dividend policies on corporate performance and firm market value. Based on a sample of 166 Greek companies listed in the Athens Stock Exchange, the empirical results confirm the importance of debt and dividends in terms of firm value creation by demonstrating a negative relationship between firm value and both leverage and dividend ratios in firms with high growth opportunities. Concerning the effect of ownership structure on firm resources, results show a positive relationship between ownership concentration and market value of firm, higher in the firms facing growth opportunities which are consistent with the idea that large shareholders have power to monitor management and reduce the free rider problem of corporate control associated with dispersed ownership.

Chen and Yur-Austin (2007) examine the efficiency of blockholders in mitigating agency costs such as managerial extravagance, poor asset management and underinvestment. Based on a sample of large publicly traded companies from 1996 to 2001, empirical results show that outside blockholders are more effective in mitigating managerial extravagance whereas inside blockholders are more vigilant about improving the efficiency of firm asset utilization. However, only managerial blockholders significantly overcome underinvestment problems, which may be attributable to their duality roles.

Nevertheless, Nekhili and al. (2009) show that the ownership concentration increases agency costs of the free cash flow in the case of the French firms

On the basis of a sample of Tunisian listed firms from 1995 to 2000, Omri (2003) show that the ownership concentration permits to reduce the managerial entrenchment and increase the possibility of the change in case of bad performance.

\section{Hypothesis $_{2}$ : Free cash flow level will be lower at higher levels of ownership concentration}

Managerial ownership has been extensively mentioned in the literature like a governance mechanism assuring the alignment of interests. Jensen and Meckling's convergence of interest' hypothesis suggest that managerial ownership serves to align the interests of mangers and outside shareholders. Indeed, managers take fewer decisions that will have some negative effects on the firm value because the part of costs that they will absorb, as shareholders, increases with their part of the capital. Therefore, managerial ownership property represents a mechanism that permits to reduce the cost of control supported by shareholders because it is supposed to reduce the managerial opportunism. However, according to the entrenchment theory, when the managerial ownership becomes very high, it becomes sometimes difficult to oust them even though their performance is judged dissatisfactory. Thus, they manage to dominate assemblies of shareholders and indirectly, all decisions taken by the firm (Daniel and Halperns, 1996), and try to reduce the possibility of takeover attempts (Stulz, 1988). The 
first developments of this theory are owed to Shleifer and Vishny (1989). The entrenchment process passes by the execution of specific investment that is going to facilitate the realization of projects in direct relation with their formation or experience, even though these are not necessarily most profitable for the firm.

Morck, Shleifer, and Vishny (1988) propose a model in which increased managerial ownership leads to entrenchment, where the manager will indulge in non-value-maximizing behavior. However, management's self-indulgence is expected to be less than if he has control but no claim on the firm's cash flows. The entrenchment hypothesis predicts that the value of the firm will decrease management ownership increases.

Poulain-Rehm (2005) tested the role of governance mechanisms in the limitation of the free cash flow problem in managerial and patrimonial listed firms. The author suggests that the effect of the ownership structure on the free cash flow affectation is not direct. The empiric results show that the impact of managerial and domestic ownership is negative and significant on the affectation of the free cash flow to the debt service for firms with low growth opportunities. This effect is rather positive in firms with high growth opportunities.

using a survey sample of approximately 3800 Australian small and medium enterprises from 1996 to 1998 Fleming, Heaney and McCosker (2005) examine how agency costs change when ownership and control are separated. Empirical results provide a positive relationship between equity agency costs and the separation of ownership and control. Specifically, it is found that agency costs are lower in firms managed by equity holders, consistent with the argument that reducing the separation of ownership and control reduces agency costs. Finally, agency costs decrease as managerial and employee equity holdings increase.

Lee and Yeo (2007) examine the association between managerial entrenchment and capital structure of Asian firms. They find a negative association between managerial entrenchment and level of leverage in firms with higher agency costs of free cash flow. Specifically, the level of leverage decrease in firms with CEO who is president of the board, lower proportion of outside directors and higher CEO tenure. The authors also show a positive relationship between institutional ownership and level of leverage which indicates that active monitoring by institutional investors diminishes entrenched managers' incentives to avoid debt.

Ghosh (2007) adopted the three stage least square simultaneous model approach to examine the interaction between leverage, ownership structure and firm value. Results show that capital structure, ownership structure and firm value are jointly determined. Specifically, the managerial ownership is a nonlinear determinant of firm leverage and also, leverage is a negative determinant of managerial ownership. These finding reveal the existence of a substitution monitoring effect between debt and managerial ownership. Then, the findings indicate that firm value decreases as promoters ownership increase. Since control of such companies can still be in the promoters' hands because of the dispersed nature of shareholding, such companies need to be subjected to more vigilant external monitors through debt and to the discipline of an active market for corporate control.

Florackis and Ozkan (2008) indicate that important governance mechanisms for the UK listed 
companies are managerial ownership, ownership concentration, executive compensation, short-term debt and, bank debt. The authors examine the interactions between these mechanisms and firm growth opportunities in determining agency costs. The results show that impact exerted by governance mechanisms on agency costs vary with firms' growth opportunities. Specifically, high-growth firms face more serious agency problems than low-growth firms due to information asymmetries between managers, shareholders and debtholders. Moreover, results reveal that managerial ownership is more effective for high-growth firms.

McKnight and Weir (2009) examine the impact of ownership structure on three measures of agency costs which are the ratio of sales-to-total assets, the interaction of free cash flows and growth prospects and the number of acquisitions agency costs. To do so, employ a range of techniques to analyze the data collected for large UK listed companies: fixed-effects, instrumental variables, and Tobit regressions the authors. Results show that the changes in board structures have not affected agency costs. This suggests a range of mechanisms is consistent with firm value maximization. Results also indicate that having a nomination committee increases agency costs, which indicates that there are costs associated with certain governance mechanisms. Increasing board ownership also helps to reduce agency costs. Finally debt reduces agency costs.

In our study we presume, in accordance with the theory of interest convergence, that as the managerial ownership increases, their behavior comes closer of the one of shareholders. It results in a limitation of the free cash flow risk.

Hypothesis ${ }_{3}$ free cash flow level will be lower at higher levels of managerial ownership.

The internationalization of financial markets made the institutional investors the major actors of the world economy given their large portfolio size. According to the OECD (2000), the institutional investors regroup four types of institutions: funds of pension, the mutual funds or investment Society, companies of insurances and the other institutional investor form as foundations or Private investment partnerships. Forester (1995) stipulates that the institutional investor presence pushes enterprises to be more conformable to recommendations of the various codes of good governance and can have an effect on the corporate performance by minimizing agency costs.

In this context, Bohn (2007) indicates that the movement of the governance benefitted from an important soaring in 2002 following the study achieved by the management consulting McKinseys \& Company concerning the institutional investors through the world, that showed that these investors would be ready to invest significant funds in the control of firms and to pay for a supplement until $40 \%$ to make a firm having good corporate governance practices.

Several studies confirmed the positive role of the institutional investors in the corporate governance. Thus, McConnel and Servaes (1990) indicate that the implication of the institutional would result in their propensity to vote in general assembly (Brickley, Lease and Smith, 1988). Their study establishes that these investors exercise their voting rights more frequently than the individual shareholders and that they don't hesitate to oppose to managers 
decisions in order to defend their interests in case of dissatisfaction.

In their seminal paper, Pound (1988) presented three hypotheses concerning the effect of institutional ownership on firm performance: efficient monitoring, conflict of interest, and strategic alignment. According to the first hypothesis, institutional investors may have a positive impact on corporate performance if they monitored the managers effectively. They held more stocks and were more professional than private investors, so they had stronger motive to inspect the listed companies. Under the second hypothesis, institutional investors are less subject to information asymmetries than are other shareholders because they have greater resources, incentives for control firms and financial resources.

Finally, the third hypothesis suggests that the institutional investors and managers find that cooperation is mutually advantageous. This cooperation reduces the beneficial effects on the firm value that could be result from the direction by the institutional investors.

According to Solh (2000), the institutional investors can influence the long-term investment decisions and encourage the company's management to choose the optimal projects from the point of view of shareholder interest.

Henry (2010) indicates that the institutional investors have a larger experience and they are more efficient monitors that the minority shareholders on the plane cost of control. Strategies that are accepted by the institutional investors are those that will be undertaken by firm through the accumulation of an important number of votes at the time of the board meeting what has the tendency to privilege the strategies creative of the value to the detriment of those destructive of the value to shareholders. Indeed, resources of which they arrange allow them to control the firm to a weaker cost that the other shareholders. It is due to the fact that they have a better access to information, because of their activity and the numerous investments that they achieve rich information on the environment and an excellent knowledge of the labor market. So institutional investors should help to facilitate the alignment of shareholder and managerial interests and, therefore, lower estimated agency costs. Darren (2010) identify the mechanisms that are effective in reducing agency costs using data for the period from 1992 to 2002 for listed companies on the Australian Stock Exchange. Empirical results indicate that institutional ownership has a negative effect on agency costs and there are non-linear relationships between managerial ownership and external ownership and the level of agency costs generated by companies. Though, the results provide limited evidence, in the effect of capital structure on agency costs. Finally, it is showed that internal governance and external shareholding influences are substitute mechanisms in their effect on the level of agency costs.

Several works test the interaction between corporate governance mechanisms. Agrawal and Knoeber (1996) examine the relationship between seven corporate governance mechanisms in mitigating agency problems between managers and shareholders. These mechanisms are: shareholdings of insiders, institutions, and large blockholders; use of outside directors, debt policy, the managerial labor market and the market for corporate control. Results show that ownership concentration and institutional ownership constitute a substitute to the external ownership. Moreover, the findings demonstrate a relation of complementarity between OPA, 
shareholdings of institutions, and large blockholders.

Kale, Ciceksever and Ryan (2006) estimate a system of three equations to analyze the interrelations among governance, debt, and activist institutional ownership as disciplining mechanisms. Using two-stage least squares, the findings of analysis indicate that mechanisms for disciplining managers serve as both substitutes (institutional ownership and debt) and complements (governance and institutional ownership)

Al - Khouri (2006), find for a sample of listed firms on the stock market of Amman during the period 1998-2001, a positive and significant relationship between the institutional ownership and the firm value proxied by Tobin $\mathrm{Q}$ whether or not institutional investors are on the board of directors. This relationship is verified provided that the part of institutional ownership exceeds $25 \%$.

$\mathrm{Wu}$ (2004) shows that in the firms with low growth opportunities, institutional investors discourage managerial overspending by governance process and hence compensate for the debt monitoring. However, in the firms with high growth opportunities, institutional investors encourage higher leverage. Thus, Author finds that the institutional substitutes ownership the leverage in controlling the managerial self-interest.

McKnight and Weir (2009), prove that at higher levels of institutional ownership, institutions become less effective in supervising managerial actions and may not moderate the agency cost problem.

Hypothesis 4 : free cash flow level will be lower at higher levels of institutional ownership.

\subsection{The previous empirical studies testing capital structure determinants}

Harris and Raviv (1991) imply that the leverage of firms may be affected by many factors as investment opportunities, advertising expenditures, fixed assets, and the possibility of bankruptcy, profitability and uniqueness of product. For our empirical purposes, we focus on size, tangibility, tax, growth opportunities, profitability, risk and industry classification.

\subsubsection{Firm size}

Theoretically, the effect of size on leverage is ambiguous. On the one hand, some authors find a positive relationship between size and leverage, for example Rajan and Zingales (1995), Huang and Song (2002), Delcoure (2007) and Pao (2008). Larger firms are much more diversified than smaller one and so have lower variance of earnings, making them able to accept high debt ratios. On the other hand, some studies report a negative relationship, for example Kim and Sorensen, (1986), Titman and Wessels, (1988), Fluck et al. (2000) and Chen (2004). Due to asymmetry information, small firms are more likely to be underpriced by investors than large firms and could not get favorable price when financing through equity (Halov and Heider, 2005). While using debt with a fixed interest rate, small firms could suffer less loss from mispricing. Thus small firms should tend to consider using more debt, compared to large firms.

Hypothesis (a): According to the static trade off theory (agency theory), the size has a 
positive impact on the leverage

Hypothesis, (b): According to the asymmetric information theory and the pecking order theory, the size has a negative impact on the leverage

\subsubsection{Tangibility}

Booth et al. (2001) state: "The more tangible the firm's assets, the greater its ability to issue secured debt." Consequently, a positive relationship between tangibility and leverage is presumed since tangible assets can be used as collateral. Also, in the case of conflict of interest between shareholders and creditors, Jensen and Mecklings (1976) demonstrated that the problem of overinvestment is less serious with more tangible assets.

Several empirical studies confirm this suggestion (Rajan and Zingales (1995), Kremp et al., (1999), Hovakimian et al., (2001), Chen (2004), Drobetz and Fix (2005), Fattouh et al., (2005), Huang and Song (2006), Delcoure (2007) Pao (2008), De Jong et al., (2008)). On the other hand, Booth et al. (2001) suggest that the relationship between tangible fixed assets and debt financing is related to the maturity structure of the debt. In such a situation, the level of tangible fixed assets may facilitate to the firms to get more long-term debt, but the agency problems may become more severe with the further tangible fixed assets, because the information revealed about future earnings is less in these firms. In this case, a negative relationship between tangible fixed assets and debt ratio is presumed.

Hypothesis 6 (a): according to the agency theory, there is a positive relationship between leverage tangibility

Hypothesis 6 (b): according to the pecking order theory, there is a negative relationship between leverage and tangibility.

\subsubsection{Taxation}

Numerous empirical studies have explored the impact of taxation on corporate financing decisions. According to the trade-off theory, a firm with a higher tax rate should issue more debt since it has more income to shield from taxes. However, for example Fama and French (1998) declare that debt has no net tax benefits. MacKie-Mason (1990) also stipulates: "Nearly everyone believes taxes must be important to financing decision, but little support has been found in empirical analysis."

Empirically, Graham and Tucker (2006) use a sample of 44 tax shelter cases to examine the degree of tax shelter activity and whether participating in a shelter is associated to debt policy. The results show that the firms use less debt when they engage in tax sheltering. The tax shelter firms appear under levered if shelters are ignored but do not appear under levered once shelters are considered.

Buettner et al. (2009), test the impact of taxes on the capital structure of German firms. The empirical analysis confirms that the local tax burden exerts important effects on an affiliate's leverage. This refers not only to external debt; the results show that a higher local tax has a positive impact on internal debt. This confirms that multinationals have access to other 
instrument which can be used to exploit the tax savings opportunities of debt finance.

Hypothesis 7: According to the trade-off theory, there is positive relationship between leverage and tax rate

\subsubsection{Growth opportunities}

Jensen (1986) suggests that in case of low growth opportunities agency costs of free cash flow rise, so, debt should be issued. In doing so, probability of overinvestment by managers is reduced as firms commit to utilize future free cash flows for paying out investors. Consequently, a negative relationship between growth opportunities and debt ratios can be predicted.

Myers (1977) indicates that high leverage reduces the incentives of the managers and shareholders to invest in profitable investment opportunities, since the benefits return to the bondholders rather than to the shareholders. Thus, highly levered firm are less likely to exploit valuable growth opportunities as compared to firm with low levels of leverage. So the values of stocks diminish when there is information that the firm will issue stocks according to the asymmetric information theory. In this case, firms should not issue stocks and must use all internal resources and then financing via debt according to the pecking order theory.

Empirically, Aivazian et al (2005) examine the effect of leverage on investment on 1035 Canadian industrial firms for the period from 1982 to 1999. They found a negative relationship between investment and leverage and that the relationship is more significant for low growth firms rather than high growth firms. Chen and Zhao (2006) find a non-monotonic and positive relationship between growth opportunities and leverage for more than $88 \%$ of COMPUSTAT firms. Billett et al. (2007) conclude that although growth opportunities negatively affect the leverage, there is a positive relationship between leverage and growth opportunities because of covenant protection. Debt covenants may attenuate the negative effect by attenuating the agency costs of debt for firms with high growth opportunities.

Hypothesis \& (a): according to the agency theory and the asymmetric information theory, there is a negative relationship between leverage and growth opportunities.

Hypothesis \& (b): according to the pecking order theory, there is a positive relationship between leverage and growth opportunities.

\subsubsection{Profitability}

There are no consistent theoretical predictions on the effects of profitability on leverage. According to the trade-off theory, more profitable firms should have higher leverage because they have more income to shield from taxes. Also, according the free cash-flow theory would suggest that more profitable firms should use more debt in order to discipline managers. However, from the point of view of the pecking-order theory, firms prefer internal financing to external. Thus more profitable firms have a lower need for external financing and consequently should have lower leverage.

Most empirical studies observe a negative relationship between leverage and profitability, for 
example (Rajan and Zingales, 1995), (Huang and Song, 2002), (Booth et al., 2001), De Jong et al., (2008) and Karadeniz et al., (2009)

Hypothesis 9 (a): according to the agency theory, there is a positive relationship between leverage and profitability.

Hypothesis 9 (a): according to the pecking order theory, there is a negative relationship between leverage and profitability.

\subsubsection{Firm risk}

Several authors stipulate that the level of leverage is a decreasing function of the gain variability. The negative relation is predicted by the Trade-off theory, the pecking order theory and the agency theory. Indeed, in a hierarchical financing perspective the volatility of profits can allow the firm to form a reserve of assets easily mobilizable in order to avoid an overinvestment problem. However, there are arguments demonstrating the effect positive of the risk on the leverage. Indeed, firms having a higher risk can also have a strategy of overinvestment that creditors have difficulty discerning because of the asymmetry of information between lenders and borrowers and will to reduce costs of agency. Huang and Song (2002) suggest based on findings of Hsia (1981): "As the variance of the value of the firm's assets increases, the systematic risk of equity decreases. So the business risk is expected to be positively related to leverage."

Empirically, the effect of risk on leverage is ambiguous. On the one hand, some authors find an inverse relationship between risk and leverage, for example Bradley et al., 1984; Titman and Wessels, 1988; Friend and Lang, 1988; MacKie-Mason, 1990; Kale et al., 1991; Kim et al., 1998). Other studies suggest a positive relationship (Jordan et al., (1998), Michaelas et al., (1999), Wiwattanakantang (1999), Kremp and Stöss (2001), Esperança et al. (2003) and Pao (2008).

Hypothesis 10 (a): according to the trade off theory and the pecking order theory, there is a negative relationship between leverage and firm risk

Hypothesis 10 (a): according to the asymmetric information theory, there is a positive relationship between leverage and firm risk

\subsubsection{Industry Classification}

Some empirical studies identify a statistically significant relationship between industry classification and leverage. Titman (1984) and Titman and Wessels (1988) show that firms manufacturing machines and equipment should be financed with relatively less debt, because they incur some very important liquidation costs. They use a dummy variable equal to one if the firm belongs to the industry sector and zero otherwise. Harris and Raviv (1991) declare, based on a survey of empirical studies: "Drugs, Instruments, Electronics, and Food have consistently low leverage while Paper, Textile Mill Products, Steel, Airlines, and Cement have consistently large leverage". More recently Awan and al., (2010) examine the relationship between growth opportunities and capital structure of the firms for sample of 110 manufacturing companies listed on Karachi Stock Exchange for 15 years (1982-1997) from 9 
different sectors. They have found a significant positive relationship between growth opportunities and leverage that is greatly significant for sectors such as textile, sugar, cement, paper and jute. The possible explanation for such leverage behavior in these sectors could be that the owners of these firms, with a nominal foreigners' representation view the available growth opportunities as unsustainable and more risky, intend to pass on a higher risk to their creditors which would result in a high debt level. Although, some empirical studies find no significant relationship between leverage and industry classification. We essentially mention the study of Drobetz and Fix (2005) for the Swiss firms and the one of Kim, Heshmati and Aoun (2006) for the non financial listed firms in Korea. For the Tunisian firms, the industrial sector grants a big importance to restructurings requiring some enormous amounts.

Hypothesis ${ }_{11}$ : The industrial firms should be financed with relatively more debt what will have as consequence the reduction of their free cash flow level.

\section{Methodology}

The review of the empirical literature treating the role of the debt and the ownership structure, as mechanism of resolution of agency conflicts between shareholders and managers due to the overinvestment problem brings us to note the contradiction and the empirical result ambiguousness don't seem again today to permit to succeed to the robust findings. It is therefore useful to spread knowledge on this topic and to see if the same factors keep in a different environment such the one of Tunisia.

\subsection{Sample Selection and definition of the variables}

\subsubsection{Sample selection}

Our sample consists of firms listed on the Tunisian stock exchange. Because banks and insurances are subject to specific rules and regulations, their leverage is severely affected by exogenous factors. So, Following Rajan and Zingales (1995), we exclude all firms categorized as "Financials" and focus exclusively on non-financial firms. Moreover, we eliminated firms not having long term debts (variable important of the model). Data used is provided by the Tunisian Stock Exchange and the Council of Capital Market through respectively their official bulletins and their annuals reports covering the period from 1998 to 2008. The analysis is about the period from 1999 to 2008 . The year 1998 serves to calculate some parameters that are variations. Our final sample consisted of 35 firms with a total of 206 firm year observations.

\subsubsection{Definition of the variables}

\subsubsection{Dependent variables}

We use two dependent variables in this study: the leverage (measured by the long term debt ratio) and the level of free cash flow.

The literature provides mixed guidance on the measures of free cash flow, which Jensen (1986) defines as cash flow left after firms have invested all available positive NPV projects. Since the value of positive NPV projects is unobservable, free cash flow is difficult to measure in practice. The most commonly used FCF definition is the one suggested by Lehn 
and Poulsen (1989). Their measure of FCF is the operating income before depreciation minus taxes, interest expenses, and preferred and common dividends. Also, some authors define it as the operational income before depreciation, capital expenditures and taxes, divided by the book value of total asset In order to eliminate any size effect (Lang and al., 1991). Gul and Tsui (1998) argue that these measures of FCF by themselves do not provide a measure of the availability of positive NPV projects. However, in combination with low growth, they suggest the existence of cash flow in excess of that required to fund positive NPV projects.

Recently, Richardson (2006) constructs a measure of free cash flow. This measure is "the cash flow from operations, plus research and development expenditure less the 'required' maintenance less the 'expected' level of investment". Richardson applies "the label 'free' cash flows to the resulting measure, which is cash flow less the assumed non-discretionary and mandated components of investment". He suggests "The stated goal is to create a measure of the amount of cash flows that are not encumbered by the need to maintain the existing assets of the firm".

In our study we measure cash flow as:

Cash flow $=0 \mathrm{O}-\mathrm{T}+\mathrm{D}-\mathrm{N2}-\Delta \mathrm{WCR}$

TA

OI: operating income

T: tax

D: depreciation

NI: Net Investment

$\Delta \mathrm{WCR}$ : change in working capital requirements TA: total assets

To take account of growth opportunities we refer to studies of Miguel and Pindado (2001) Pindado and De la Torre (2009) and Nekhili et al. (2009), and we are going to measure the risk of free cash flow while multiplying free cash flow by the inverse of the Tobin Q. This last is measured like Dennis and al. (1994) which is market value of equity divided by book value of equity

Also, in accordance with Nekhili et al., (2009), we consider the Tobin Q at the year t-1. The authors argue that investments that are determined at the year $t$ concern growth opportunities relative at the year $\mathrm{t}-1$.

froo cowh flow rigle $1, t-\frac{7 c z t, t}{\text { Tobing it }-1}$

Surprisingly, there is no clear-cut definition of leverage in the academic literature. The specific choice depends on the objective of the analysis. On one hand, the total debt ratio has been used by several authors (Kremp and Stöss (2001) and Hovakimian 2005). Whereas Rajan and Zingales (1995) asserts that a ratio that includes the total debts doesn't constitute a good indicator, notably to put in exergue risks of bankruptcy of the firm. However, the short-term debt ratio has also been used by Titman and Wessels (1988). On another hand, some authors use the market value of debts as Taggart (1977), Titman and Wessels (1988), Flannery and 
Rangan (2006). Other authors as Benett and Donnelly (1993), Chang, Lee and Lee (2008), Huang and Song (2006) used both market value and book value of debt. In our study, we use the same definition of leverage as Lang et al(1996), namely the ratio of the book value of long-term debt to the book value of total assets in order to not neutralize the impact of agency costs joined to the leverage(Myers, 1977). This measure would not reflect recent changes in the markets. This measure has been used by Mello and Miranda (2010) who investigate the role of long-term debt in influencing over investments by analyzing the pattern of abnormal investments around a new debt offering by unleveraged firms. Pao (2008) precise that all studies that are interested in determinants of the capital structure judged that the difference between the market value of debt is very close to book value of debt.

\section{Laverage $=\frac{\text { boorwate of long wern aete }}{\text { book walue of total asgets }}$}

\subsubsection{Independent variables}

A detailed discussion of the variable construction is presented in Table 1.

Three explanatory variables are included as control variables on the basis of prior studies that investigate the determinants of free cash flow: state ownership, firm size and industry classification. According to the agency theory, state ownership is reputed to be inefficient due to the lack of capital market monitoring. Thus, it would incite their managers to pursue their own interests instead of those of their institutions. Managers of the private firms will have a stronger pressure of their environment and a more intense disciplinary effect from the capital market which can considerably reduce the inefficiency of these firms, (Lang and So, 2002). Indeed, through the control by goods and services market (competitive pressure of the sector), the badly managed companies should naturally disappear. However, often, public corporations are in position of monopoly and have not competitors. Besides, through the control by the financial market, badly managed firms constituent targets for the more effective acquirers. However, stocks detained by the state are generally non transferable and the state imposes a strict control on partners. Also, the diffusion of information concerning the firm to the capital market is often confused (political considerations, rules of public accounting). Also, managers who are members of the board of directors have no interest to contest the president decisions being discerned like emanating from the government. So we presume a negative relationship between state ownership and

Firm size (proxy as logarithm of total assets) is used to explain the complexity of the surveillance required in the largest firms. We presume a negative relationship between the size and the risk of free cash flow in accordance with Jensen (1986), that precise that large firms, had much cash flow, would prefer debt financing in order to discipline managers what limits the risk of free cash flow. For the variable "industry" we anticipate that his sign is negative. Indeed, following restructurings of the Tunisian industrial firms, these will issue debts, what minimizes the level of free cash flow. 
Table 1. Definition and measurement of the variables

\begin{tabular}{|c|c|c|}
\hline & Code & Proxy \\
\hline \multicolumn{3}{|r|}{ Dependent variables } \\
\hline Leverage & Lev & 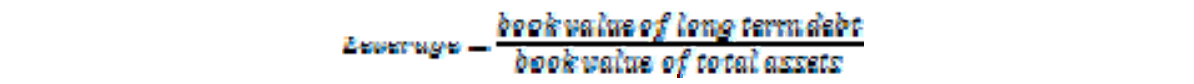 \\
\hline $\begin{array}{l}\text { Free Cash Flow } \\
\text { Risk }\end{array}$ & FCF & 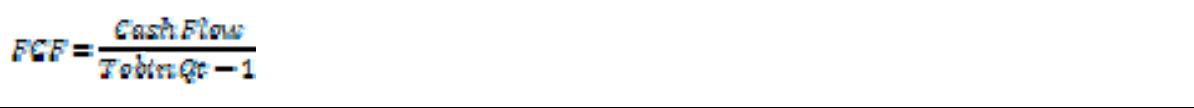 \\
\hline \multicolumn{3}{|r|}{ Independent variables } \\
\hline Firm size & Size & Log (Total Assets) \\
\hline Fixed assets & Tang & Trng $=\frac{\text { Tengtblesuretz }+ \text { Stack }}{\text { Totslsagets }}$ \\
\hline Profitability & Profit & 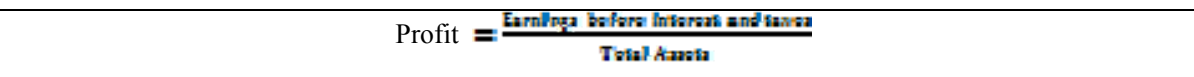 \\
\hline Tax paid & Tax & 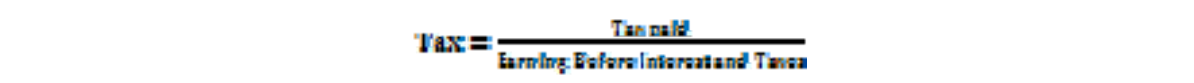 \\
\hline Operational risk & Risk & 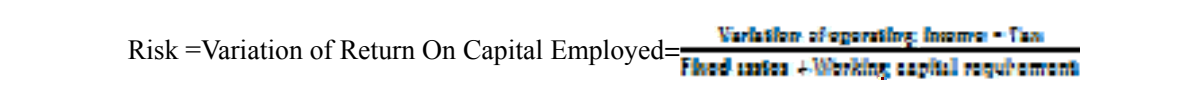 \\
\hline $\begin{array}{l}\text { Growth } \\
\text { opportunities }\end{array}$ & Growth & Total assets total $_{\text {assets }} \mathrm{t}_{-1} /$ total assets $\mathrm{t}_{\mathrm{t}-1}$ \\
\hline $\begin{array}{l}\text { Industry } \\
\text { classification }\end{array}$ & Ind & Dummy variable equal to one if the firm belongs to the industry sector and zero otherwise \\
\hline $\begin{array}{l}\text { Managerial } \\
\text { ownership }\end{array}$ & Man & Man $=\frac{\text { Amountof ahsres thst were onmed by direstorr snd member of the basrd }}{\text { Total of ahsre }}$ \\
\hline $\begin{array}{l}\text { Ownership } \\
\text { concentration }\end{array}$ & Conc & $\begin{array}{l}\text { Percentage of share owned by the largest five shareholders in a firm. } \\
\text { Conc }=2 * 2 \text { Vk; K represents the kème sharedolder in a rank of decreasing order of importance }\end{array}$ \\
\hline $\begin{array}{l}\text { Institutional } \\
\text { ownership }\end{array}$ & Inst & 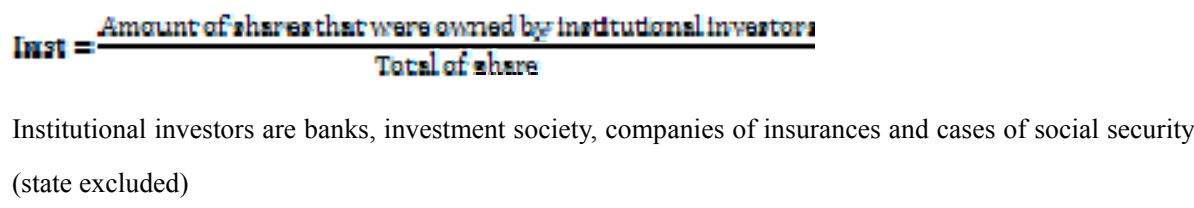 \\
\hline State ownership & State & 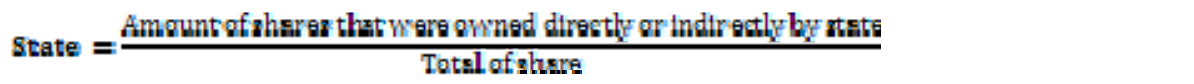 \\
\hline
\end{tabular}




\subsection{Descriptive Statistics}

Table 2. Descriptive Statistic of the variables

\begin{tabular}{|l|c|c|c|c|c|}
\hline & Observation & Mean & Stdv & min & max \\
\hline FCF & 206 & 0,173 & 0,239 & $-0,415$ & 1,235 \\
\hline Leverage & 206 & 0,200 & 0,270 & 0,0002 & 2,254 \\
\hline Conc & 206 & 0,708 & 0,130 & 0,274 & 0,961 \\
\hline Man & 206 & 0,233 & 0,295 & 0,000 & 1,000 \\
\hline Inst & 206 & 0,236 & 0,240 & 0,000 & 0,880 \\
\hline State & 206 & 0,277 & 0,293 & 0,000 & 0,880 \\
\hline Size & 206 & 10,963 & 0,892 & 9,240 & 14,205 \\
\hline Tang & 206 & 0,494 & 0,163 & 0,143 & 0,869 \\
\hline Tax & 206 & 0,087 & 0,091 & $-0,159$ & 0,361 \\
\hline Growth & 206 & 0,078 & 0,176 & $-0,241$ & 1,391 \\
\hline Profit & 206 & 0,074 & 0,079 & $-0,237$ & 0,282 \\
\hline Risk & 206 & $-0,001$ & 0,091 & $-0,551$ & 0,395 \\
\hline
\end{tabular}

Table 2 shows the statistic descriptive of the characteristic of the endogenous and exogenous variables in the relationship between debt policy, free cash flow and ownership structure of this study. It is mainly about the non weighted averages, of standard deviation as well as of the minimal and maximal values of distributions. Mean value of the debt ratio (leverage) is $0,20(20 \%)$. Minimum value of using debt is $0,0002(0,02 \%)$ and maximum value is 2,254 $(200,254) \%$ with standard deviation is 0,27 (27\%). Otherwise, an important stylized fact on Tunisian firms is the concentration of the ownership whose mean value is $0,708(70,8 \%)$. Besides, mean value of the managerial ownership is $23,3 \%$ with a maximum that reaches $100 \%$. Managers and administrators of the Tunisian firms hold a strong proportion of the capital therefore what sustains the join of functions of ownership and control. Finally, we note that the institutional ownership is restraint. It is on average equal to $23,6 \%$.

According to the free cash flow theory, the divergence of interest between shareholders and managers should be the most severe in the firms with few growth opportunities and large free cash flow. Hence the relations between ownership structure, free cash flow and leverage are most important for these firms. Following the study of Nekhili and al., (2009) and Awan And al., (2010), we decompose our sample in two groups of firms depending on whether their level of free cash flow is low or high in order to determine variables can characterize every group. The first decomposition (table 3) is based on the "mean criteria". While, the second decomposition (table 4) is based on the "median criteria". 
Table 3. Provides descriptive statistics for low-fcf and high-fcf firms.

\begin{tabular}{|c|c|c|c|c|c|}
\hline Variables & & $\begin{array}{l}\text { Total sample } \\
(\mathrm{Nb}=206)\end{array}$ & $\begin{array}{c}\text { Group } 1 \text { : low FCF } \\
(\mathrm{Nb}=127)\end{array}$ & $\begin{array}{c}\text { Groupe } 2 \text { : high FCF } \\
\qquad(\mathrm{Nb}=79)\end{array}$ & $\begin{array}{l}\text { T statistic } \\
\text { (p-value) }\end{array}$ \\
\hline Leverage & $\begin{array}{l}\text { Mean } \\
\text { Stddeviation } \\
\text { Min } \\
\text { Max }\end{array}$ & $\begin{array}{l}0,200 \\
0,270 \\
0,000 \\
2,254\end{array}$ & $\begin{array}{l}0,187 \\
0,267 \\
0,000 \\
2,254\end{array}$ & $\begin{array}{l}0,224 \\
0,276 \\
0,000 \\
2,075\end{array}$ & $\begin{array}{c}-2,3229^{* *} \\
-0,021\end{array}$ \\
\hline Man & $\begin{array}{l}\text { Mean } \\
\text { Stddeviation } \\
\text { Min } \\
\text { Max }\end{array}$ & $\begin{array}{l}0,233 \\
0,295 \\
0,000 \\
1,000\end{array}$ & $\begin{array}{l}0,238 \\
0,138 \\
0,303 \\
1,000\end{array}$ & $\begin{array}{l}0,226 \\
0,144 \\
0,328 \\
0,890\end{array}$ & $\begin{array}{l}-0,282 \\
-0,779\end{array}$ \\
\hline Inst & $\begin{array}{l}\text { Mean } \\
\text { Stddeviation } \\
\text { Min } \\
\text { Max }\end{array}$ & $\begin{array}{l}0,236 \\
0,240 \\
0,000 \\
0,880\end{array}$ & $\begin{array}{l}0,250 \\
0,235 \\
0,000 \\
0,880\end{array}$ & $\begin{array}{l}0,213 \\
0,248 \\
0,000 \\
0,880\end{array}$ & $\begin{array}{l}-2,3340^{* *} \\
-0,021\end{array}$ \\
\hline Conc & $\begin{array}{l}\text { Mean } \\
\text { Stddeviation } \\
\text { Min } \\
\text { Max }\end{array}$ & $\begin{array}{l}0,708 \\
0,130 \\
0,274 \\
0,961\end{array}$ & $\begin{array}{l}0,685 \\
0,130 \\
0,274 \\
0,946\end{array}$ & $\begin{array}{l}0,749 \\
0,121 \\
0,475 \\
0,961\end{array}$ & $\begin{array}{l}-0,500 \\
-0,618\end{array}$ \\
\hline Size & $\begin{array}{l}\text { Mean } \\
\text { Stddeviation } \\
\text { Min } \\
\text { Max }\end{array}$ & $\begin{array}{c}10,963 \\
0,892 \\
9,240 \\
14,205\end{array}$ & $\begin{array}{l}10,972 \\
0,874 \\
9,560 \\
14,108\end{array}$ & $\begin{array}{l}10,947 \\
0,928 \\
9,240 \\
14,205\end{array}$ & $\begin{array}{c}2,2482 * * \\
-0,026\end{array}$ \\
\hline State & $\begin{array}{l}\text { Mean } \\
\text { Stddeviation } \\
\text { Min } \\
\text { Max }\end{array}$ & $\begin{array}{l}0,274 \\
0,292 \\
0,000 \\
0,880\end{array}$ & $\begin{array}{l}0,173 \\
0,300 \\
0,000 \\
0,748\end{array}$ & $\begin{array}{l}0,342 \\
0,250 \\
0,000 \\
0,880\end{array}$ & $\begin{array}{l}-4,178 \\
(0,0000) \\
* * *\end{array}$ \\
\hline
\end{tabular}




\section{Macrothink}

Table 4. Provides descriptive statistics for low-fcf and high-fcf firms

\begin{tabular}{|c|c|c|c|c|c|}
\hline Variables & & $\begin{array}{l}\text { Total sample } \\
\text { (Nb = 206) }\end{array}$ & $\begin{array}{c}\text { Group } 1 \text { : low } \\
\text { fcf } \\
(\mathrm{Nb}=103)\end{array}$ & $\begin{array}{c}\text { Group } 2 \text { : high } \\
\text { fcf } \\
(\mathrm{Nb}=103)\end{array}$ & $\begin{array}{l}\text { T statistic } \\
\text { (p-value) }\end{array}$ \\
\hline Leverage & $\begin{array}{l}\text { Mean } \\
\text { Stddeviation } \\
\text { Min } \\
\text { Max }\end{array}$ & $\begin{array}{l}0,200 \\
0,270 \\
0,000 \\
2,254\end{array}$ & $\begin{array}{l}0,138 \\
0,349 \\
0,000 \\
2,254\end{array}$ & $\begin{array}{l}0,263 \\
0,131 \\
0,000 \\
0,681\end{array}$ & $\begin{array}{c}3,3884 * * * \\
-0,001\end{array}$ \\
\hline Man & $\begin{array}{l}\text { Mean } \\
\text { Stddeviation } \\
\text { Min } \\
\text { Max }\end{array}$ & $\begin{array}{l}0,233 \\
0,295 \\
0,000 \\
1,000\end{array}$ & $\begin{array}{l}0,231 \\
0,133 \\
0,303 \\
0,880\end{array}$ & $\begin{array}{l}0,243 \\
0,153 \\
0,303 \\
1,000\end{array}$ & $\begin{array}{l}-0,914 \\
-0,362\end{array}$ \\
\hline Inst & $\begin{array}{l}\text { Mean } \\
\text { Stddeviation } \\
\text { Min } \\
\text { Max }\end{array}$ & $\begin{array}{l}0,236 \\
0,240 \\
0,000 \\
0,880\end{array}$ & $\begin{array}{l}0,283 \\
0,268 \\
0,000 \\
0,880\end{array}$ & $\begin{array}{l}0,190 \\
0,199 \\
0,000 \\
0,780\end{array}$ & $\begin{array}{c}2,848 \\
(0,0049)^{* * *}\end{array}$ \\
\hline Conc & $\begin{array}{l}\text { Mean } \\
\text { Stddeviation } \\
\text { Min } \\
\text { Max }\end{array}$ & $\begin{array}{l}0,708 \\
0,130 \\
0,274 \\
0,961\end{array}$ & $\begin{array}{l}0,698 \\
0,124 \\
0,430 \\
0,926\end{array}$ & $\begin{array}{l}0,719 \\
0,136 \\
0,274 \\
0,961\end{array}$ & $\begin{array}{l}-1,183 \\
-0,238\end{array}$ \\
\hline Size & $\begin{array}{l}\text { Mean } \\
\text { Stddeviation } \\
\text { Min } \\
\text { Max }\end{array}$ & $\begin{array}{l}10,963 \\
0,892 \\
9,240 \\
14,205\end{array}$ & $\begin{array}{r}11,011 \\
0,996 \\
9,560 \\
14,108\end{array}$ & $\begin{array}{r}10,916 \\
0,776 \\
9,240 \\
14,205\end{array}$ & $\begin{array}{r}0,759 \\
-0,449\end{array}$ \\
\hline State & $\begin{array}{l}\text { Mean } \\
\text { Stddeviation } \\
\text { Min } \\
\text { Max }\end{array}$ & $\begin{array}{l}0,274 \\
0,292 \\
0,000 \\
0,880\end{array}$ & $\begin{array}{l}0,191 \\
0,306 \\
0,000 \\
0,761\end{array}$ & $\begin{array}{c}0,357 \\
0,253 \\
0,000 \\
0,880\end{array}$ & $\begin{array}{c}4,2486^{* * *} \\
0,000\end{array}$ \\
\hline
\end{tabular}

Table (3) and table (4) show that firms having a high level of free cash flow (79) are different of those having a low level of free cash flow (127). Indeed, high-fcf firms have higher amount of debt in their capital structure than low-fcf firms. The mean leverage for high-fcf firms is 22,4 percent, compared to a mean of 18.7 percent for low-fcf firms. This is consistent with the free cash flow hypothesis in which firms with higher fcf and fewer growth opportunities have higher levels of leverage. There is also evidence that ownership structure differs between the two subsamples. The mean managerial ownership for high-fcf firms is 24,3 percent, compared to a mean of 23,1 percent for low-fcf firms Nevertheless, the mean institutional ownership for high-fcf firms is 21.3 percent compared to a mean of 25 percent for low-fcf firms. Low-fcf firms have lower concentration ownership. The mean concentration ownership for low-fcf firms is 68.5 percent, compared to a mean of 74.9 
percent for high-fcf firms. It appears, therefore, that some governance mechanisms of governance intervene as soon as the level of the free cash flow increases.

To estimate our models we must examinate if there is presence of a multicollinearity problem.

Multicollinearity refers to a situation in which two or more explanatory/independent variables in multiple regression models are highly correlated. It can be detected through analyzing the Pearson correlation matrix. If the Pearson correlation coefficient exceed 0,7 (limit fixed by Kervin, 1992), we conclude the presence of multicollinearity.

Table (5) present the correlation coefficient associated to independent variables used in our models.

Results in table (5) indicate that all Pearson correlation coefficients are less than 0,7. Thus, we conclude the absence of a multicollinearity problem.

Table 5. the correlation matrix of the independent variables

\begin{tabular}{|l|l|l|l|l|l|l|l|l|l|l|l|l|}
\hline & Leverage & FCF & Size & Tang & Tax & Growth & Profit & Risk & Conc & Man & Inst & State \\
\hline Leverage & 1 & & & & & & & & & & & \\
\hline FCF & -0.144 & 1 & & & & & & & & & & \\
\hline Size & 0.156 & -0.086 & 1 & & & & & & & & & \\
\hline Tang & -0.043 & -0.107 & -0.061 & 1 & & & & & & & & \\
\hline Tax & -0.282 & 0.149 & -0.207 & -0.139 & 1 & & & & & & & \\
\hline Growth & -0.185 & -0.033 & -0.005 & -0.008 & 0.092 & 1 & & & & & & \\
\hline Profit & -0.511 & 0.247 & -0.121 & -0.196 & 0.500 & 0.175 & 1 & & & & & \\
\hline Risk & 0.005 & 0.001 & -0.037 & -0.057 & 0.067 & -0.093 & 0.160 & 1 & & & & \\
\hline Conc & 0.316 & 0.241 & 0.244 & -0.098 & -0.086 & -0.091 & -0.184 & -0.004 & 1 & & & \\
\hline Man & -0.110 & -0.112 & -0.238 & -0.079 & -0.204 & 0.056 & 0.090 & -0.0035 & 0.032 & 1 & & \\
\hline Inst & 0.404 & -0.130 & 0.050 & 0.186 & -0.095 & -0.035 & -0.307 & 0.089 & 0.104 & -0.316 & 1 & \\
\hline State & 0.3387 & -0.318 & 0.315 & 0.205 & 0.109 & -0.127 & -0.37 & -0.005 & 0.261 & -0.642 & 0.401 & 1 \\
\hline
\end{tabular}

\subsection{Specification of the simultaneous equations model and method of estimation}

A simultaneous equations approach particularly 3SLS is deemed to be appropriate on the basis of the interrelationships among the agency-cost-reducing mechanisms. This study uses a two-equation model with free cash flow and leverage as the dependent variables. Additional leverage appears as a regressor in the free cash flow equation and vice-versa. Thus, the leverage and free cash flow are simultaneously determined.

$$
\left\{\begin{aligned}
\text { FCF }_{i, t}=\alpha_{0} & +\alpha_{1} \text { Leverage }_{i, t}+\alpha_{2} \text { Conc }_{i, t}+\alpha_{3} \text { Man }_{i, t}+\alpha_{4} \text { Inst }_{i, t}+\alpha_{5} \text { State }+\alpha_{6} \text { Size }_{i, t}+\varepsilon_{1 i, t} \\
\text { Leverage }_{i, t}= & \beta_{0}+\beta_{1} F C F_{i, t}+\beta_{2} \text { Tang }_{i, t}+\beta_{3} \text { Tax }_{i, t}+\beta_{4} \text { Growth }_{t}+\beta_{5} \text { Size }_{i, t} \\
& +\beta_{6} \text { Profit }_{i, t}+\beta_{7} \text { Risk }_{i, t}+\beta_{8} \text { Ind }_{i, t}+\varepsilon_{2 i}
\end{aligned}\right.
$$


Free cash flow equation includes long term debt (Leverage), ownership concentration (Conc), managerial stock ownership (Man), institutional ownership (Inst), state ownership (State) and size of the firm (Size). While leverage equation, includes measures of level of free cash flow (FCF), firm size (Size), tangible assets (Tang), tax paid (Tax), asset growth (Growth), earning (profit), variation of the economic profitability rate (Risk) and industry (Ind).

$\varepsilon_{1 \mathrm{it}}=\mathrm{a}_{1 \mathrm{i}}+\mu_{1 \mathrm{it}}$

$\varepsilon_{2 \mathrm{it}}=\mathrm{a}_{2 \mathrm{i}}+\mu_{2 \mathrm{it}}$

$\mathrm{i}=1$,

$\mathrm{N}$ and $\mathrm{t}=1$, $\mathrm{T}$

$\mathrm{N}$ : the number of firms and $\mathrm{T}:$ the estimation period

$\varepsilon_{1 \text { it }}$ and $\varepsilon_{2 i t}$ : Error Term corresponding respectively to the first and to the second equation, $\alpha_{1} \ldots \ldots \alpha_{5}$ : representative parameters of the relative weight of each exogenous variable on the variable to explain « Free Cash Flow»;

$\beta_{1} \ldots \ldots \beta_{8}$ : representative parameters of the relative weight of each exogenous variable on the variable to explain «leverage »

$\alpha_{0}$ and $\beta_{0}$ : constants corresponding respectively to the first and to the second equation.

3.3.1. The identification condition in the model.

Order conditions are determined equation by equation. They are verified when the number of endogenous variables excluded $\left(\mathrm{k}-\mathrm{k}^{\prime}\right)$ plus the number of exogenous variables excluded $(\mathrm{g}-$ $\left.\mathrm{g}^{\prime}\right)$ is superior or equal to the number of equations less 1 : $\left(\mathrm{k}-\mathrm{k}^{\prime}\right)+\left(\mathrm{g}-\mathrm{g}^{\prime}\right) \geq(\mathrm{e}-1)$.

The equation is under - identified if $\left(\mathrm{k}-\mathrm{k}^{\prime}\right)<\left(\mathrm{g}^{\prime}-1\right)$

The equation is exactly identified if $\left(\mathrm{k}-\mathrm{k}^{\prime}\right)=\left(\mathrm{g}^{\prime}-1\right)$

The equation is over - identified if $\left(\mathrm{k}-\mathrm{k}^{\prime}\right)>\left(\mathrm{g}^{\prime}-1\right)$

With:

g: number of endogenous variables of the model;

k: number of exogenous variables of the model;

g': number of endogenous variables introduced in an equation;

$\mathrm{k}^{\prime}$ : number of exogenous variables introduced in an equation;

Rank conditions assure here that the model, under its reduced form, possesses a unique solution. The rank conditions for empirical identification are relatively complicated.

A simultaneous linear equation model is identified if all the equations are identified. 


\section{Macrothink}

Table 6. The identification condition in the model

\begin{tabular}{|l|l|l|l|l|l|l|l|}
\hline Equation & g & $\mathbf{k}$ & g' & k' & k-k' & g'-1 & Identification \\
\hline Equation 1 & 2 & 11 & 2 & 5 & 6 & 1 & k-k'> g'-1; The equation is over - identified \\
\hline Equation 2 & 2 & 11 & 2 & 7 & 4 & 1 & k-k'> g'-1; The equation is over - identified \\
\hline
\end{tabular}

\subsubsection{Method of estimation}

The model describes below is a simultaneous equations model of the leverage and the level of free cash flow. We can estimate parameters of the system when equations are exactly-identified or over - identified. We distinguish limited information method and full information method. The first consist in estimating equation by equation the model by the two stage least square method. The second consider the model in its totality and we use here the three stage least square method (Cadoret et al. (2004)). Our model will be estimated by the three stage least square method with 206 observations on the period 1999-2008. The system of two simultaneous equations, for every firm $i$ and every year $t$, can be written:

$$
y=Z \bar{Q}+s
$$

as,

$$
y=\left[\begin{array}{l}
y_{1} \\
y_{2}
\end{array}\right]=\left[\begin{array}{ccc}
Z_{1} & 0 & 0 \\
0 & Z_{2} & 0
\end{array}\right]\left[\begin{array}{l}
\delta_{1} \\
\tilde{\delta}_{2}
\end{array}\right]+\left[\begin{array}{l}
c_{1} \\
\varepsilon_{2}
\end{array}\right]
$$

as :

$y^{\prime}=\left(y_{1}, y_{2}\right)$ is vector of endogenous variables (free cash flow and long term debt)

Vectors of the explanatory endogenous and exogenous variables of the equation of free cash flow $Z_{1}$ and the level of leverage $Z_{2}$, are:

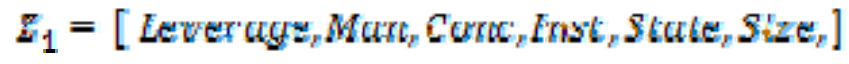

\section{$Z_{2}=[E G F, S t z e$, tang, Tax, GrQwt, Proftt,Rtsk, Ind $]$}

$\delta_{z}$ represent the vector of coefficients of all explanatory variables (endogenous and exogenous).

For error term :

$E(a)=\mathbb{a}$ 
$E\left(s a^{\prime}\right)=\left[\sigma_{s h} I\right]$ is the variance-covariance matrix

In the case of the simultaneous equations, the interdependence of endogenous variables deal place to an interdependence of error terms, what calls at the time of the estimation on the three least square method. This method consists in estimating the system in three stages. The first two stages are those of the two least square method applied separately to every equation of the system under its reduced form. Therefore, in our case we have three equations to estimate. The reduced form of the system is gotten by the application of the following stages: while using vectors (7), we can define a matrix B of three endogenous variable coefficients and a matrix A of exogenous variable coefficients as:

$$
\begin{aligned}
& y^{\prime}=(B-I)^{\prime}+X^{\prime} A=\varsigma \\
& y^{\prime}=-X^{\prime} A(B-I)^{t-1}+\varsigma^{\prime}(B-I)^{t-1} \\
& y^{\prime} \equiv X \Pi+v \\
& \Pi \equiv-A^{\prime}(B-I)^{t-1} \\
& \Pi_{h} \quad \text { and } \Pi_{h}^{\prime} \text { the generic elements of the matrix } \\
& v^{\prime} \equiv \varsigma(B-I)^{t-1}
\end{aligned}
$$

The variance-covariance matrix of error terms $E\left[v v^{\prime}\right]$ is:

$$
E\left[v v^{\prime}\right]=(B-I)^{-1} \sum \Omega I(B-I)^{t-1}
$$

Then, the reduced form of the explicit system is the following:

$$
\begin{aligned}
& F C F_{i t}=\Pi_{0}^{\prime}+\Pi_{1}^{\prime} \text { Leverage }_{t}+\Pi_{2}^{\prime} \text { Conc }_{i t}+\Pi_{3}^{\prime} \text { Man }_{i t}+\Pi_{4}^{\prime} \text { Inst }_{i t}+\Pi_{5}^{\prime} \text { State }+\Pi_{6}^{\prime} \text { Size }_{i t}+v_{1}^{\prime} \\
& \text { Leverage }_{i t}=\Pi_{0}^{\prime}+\Pi_{1}^{\prime} F C F_{i, t_{1}}+\Pi_{2}^{\prime} \text { Size }_{0}+\Pi_{3}^{\prime} \text { Tang }_{i t}+\Pi_{4}^{\prime} \text { Tax }_{i t}+\Pi_{5}^{\prime} \text { Growth }_{t t}+\Pi_{6} \text { Profit }_{i t} \\
& +\Pi_{7}^{\prime} \text { Risk }_{i t}+\Pi_{8}^{\prime}{\text { Ind }+v_{2}^{\prime}}^{\prime}
\end{aligned}
$$

To this level the evaluation is done while applying the ordinary least square method, and we get $\hat{\Pi}$ the estimator of $\Pi$

$$
\hat{\Pi}=\left(X^{\prime} X\right)^{-1} X^{\prime} y
$$


This method permits us to get values $\hat{y}_{1}$ and $\hat{y}_{2}$ serving to get the instrumental variables in the two equations. The following procedure consists in estimating every equation of the structural system while using the gotten instruments while applying the two least square method (2SLS). So, we get an estimator $\hat{\sigma}_{s}$. The objective will be to construct the estimated matrix of variance - covariance matrix of error terms that is going to be used like ponderation matrix whose generic element $\hat{\sigma}_{i j}$ is:

$$
\hat{\sigma}_{i j}=\frac{\left(y_{i}-Z_{i} \hat{\delta}_{i}\right)\left(y_{j}-Z_{j} \hat{\delta}_{j}\right)}{n}
$$

$\mathrm{n}$ : the number of years.

The third and last stage consists in estimating simultaneously the two equations with the triple least square method (3SLS).

\section{Empirical results and discussion}

Three stage east square results

Results of the joint estimation of free cash flow level and debt policy are presented at panel A, and panel B of Table 7.

Table 7. Estimated coefficients for the leverage and free cash flow using Thtree-Stage Least Squares Method (3SLS)

Panel A: Equation 1: $F C F_{i, t}=\alpha_{0}+\alpha_{1}$ Leverage $_{i, t}+\alpha_{2}$ Conc $_{i, t}+\alpha_{3}$ Man $_{i, t}+\alpha_{4}$ Inst $_{i, t}+\alpha_{5}$ State $_{i, t}+\alpha_{6}$ Size $_{i, t}+\varepsilon_{2 i, t}$

\begin{tabular}{|c|r|r|r|}
\hline Variable & Coefficient & \multicolumn{1}{|c|}{ t-Statistic } & \multicolumn{1}{c|}{ Prob. } \\
\hline Constant & 0,107 & 0,630 & 0,526 \\
\hline Leverage & $-0,191$ & $-1,650^{*}$ & 0,099 \\
\hline Conc & 0,987 & $8,880^{* * *}$ & 0,000 \\
\hline Man & $-0,569$ & $-0,569^{* * *}$ & 0,000 \\
\hline Inst & $-0,033$ & $-0,033$ & 0,629 \\
\hline State & $-0,670$ & $-0,671^{* * *}$ & 0,000 \\
\hline Size & $-0,024$ & $-0,024^{*}$ & 0,096 \\
\hline R-squared & \multicolumn{3}{|c|}{0,4887} \\
\hline Number of observation & \multicolumn{3}{|c}{} \\
\hline
\end{tabular}


Panel B: Equation 2: Leverage $_{i, t}=\beta_{0}+\beta_{1} F C F_{i, t}+\beta_{2}$ Tang $_{i, t}+\beta_{3}$ Tax $_{i, t}+\beta_{4}$ Growth $_{i, t}+\beta_{5}$ Size $_{i, t}+\beta_{6}$ Profit $_{i, t}+\beta_{7}$ Risk $_{i, t}+\beta_{8}$ Ind $_{i, t}+\varepsilon_{1 i, t}$

\begin{tabular}{|c|c|c|c|}
\hline Variable & Coefficient & t-Statistic & Prob. \\
\hline Contant & 0,204 & 0,920 & 0,360 \\
\hline FCF & 0,625 & $2,14^{* *}$ & 0,032 \\
\hline Size & 0,025 & 1,330 & 0,185 \\
\hline Tang & $-0,268$ & $-2,600^{* * *}$ & 0,009 \\
\hline Tax & $-0,141$ & $-0,700$ & 0,483 \\
\hline Growth & $-0,085$ & $-0,940$ & 0,345 \\
\hline Profit & $-1,697$ & $-6,870^{* * *}$ & 0,000 \\
\hline Risk & 0,184 & 1,150 & 0,248 \\
\hline Ind & 0,016 & 0,390 & 0,694 \\
\hline R-squared & \multicolumn{3}{|l}{} \\
\hline Number of observation & \multicolumn{3}{|l}{} \\
\hline
\end{tabular}

* Significant at the 0.10 level. ** Significant at the 0.05 level. *** Significant at the 0.01 level.

\subsection{The impact of debt policy on free cash flow levels}

The findings suggest that there is a significant impact of leverage which serves as a monitoring device to mitigate agency problem between owner and principal. The leverage variable has the negative predicted sign in the free cash flow equation and is statistically significant at the 0.01 level. Our hypothesis $\mathrm{H}_{1}$ (a) concerning the relation between the leverage and the free cash flow is therefore confirmed which corroborates the hypothesis of free cash flow of Jensen (1986) and confirms the empirical study of Wu (2004) who explore the implications of the free cash flow hypothesis concerning the disciplinary role of ownership structure in corporate capital structure policy. The author finds that the sensitivity of ownership structure to leverage depends on growth opportunities and free cash flow. When firms in the sample are classified as low-growth and high-growth firms, relation between leverage and free cash flow are significantly greater for low-growth firms than for the high-growth firms. Moreover, we observe evidence that firms with more severe overinvestment problem have higher levels of leverage and the coefficient of free cash flow are significantly positive, consistent with the free cash flow hypothesis. Also, our result corroborates the previous result of D'Mello and Miranda (2010) who shows that issuing debt leads to a dramatic reduction in this form of overinvestment and within three years of the offering the sample firms' cash ratios are similar to their industry benchmarks. Also, these relations are stronger for firms that have poor investment opportunities relative to other sample firms implying that debt plays an especially important role in reducing excess investments in firms that have the highest agency problems.

However, our result contradicts the empirical evidence of Nekhili et al., (2009) who show 
that it is distribution of dividends - rather than debt level - that leads to reduction of free cash flow.

In sum, our results indicate that debt plays a critical role in reducing the agency costs of free cash flow in Tunisian firms.

\subsection{The impact of ownership structure on free cash flow levels}

Our results show that the coefficient associated to the ownership concentration has a positive and significant sign at the 0.01 level what demonstrate that Companies characterized by the presence of a large blockholder have higher risk of free cash flow. Our result confirms the result of Nekhili et al., (2009) for the case of the French firms. Authors explain these findings by 3 arguments. First, the majority shareholders undertake nonprofit investments with other firms that are affiliated to them. Secondly, the majority shareholders cannot acquire all information detained by managers. Third, the limited relationship that shareholders maintain with the entrenched managers doesn't permit them to criticize their choices.

However, results show that the coefficient of the variable "Man" is negative and statistically significant at the 0.01 level, in accordance with Jensen and Meckling's convergence of interest' hypothesis which suggest that managerial ownership serves to align the interests of mangers and outside shareholders. So, when managerial ownership increase, the risk to waste the free cash flow is limited and managers take fewer decisions that will have some negative effects on the firm value because the part of costs that they will absorb, as shareholders, increases with their part of the capital.

Our result corroborates Nekhili et al., (2009) and McKnight and Weir (2009) who suggest that increasing internal ownership helps to reduce agency costs.

Otherwise, analysis showed that institutional ownership had a non-significant effect on free cash flow. The non significant impact can be explained by the restricted part detained by the institutional investors in the capital of the Tunisian listed firms. Our findings corroborate the neutrality thesis of ownership structure developed by Demsetz (1983), Demsetz and Lehn (1985), and Demsetz and Villalonga (2001).

The coefficient of variable "State" is significant. We find a negative correlation between level of free cash flow and the state ownership at the 0.01 level which is in concordance with our hypothesis. As state ownership increases, there is more pressure on management to limit the wasting of free cash flow. Our results bring accusation a quasi - evident conclusion admitted by economists which is the primacy of the private sector. Also, they put in exergue the importance of public firms. In fact, these firms not only fill several social objectives but control also the behavior of managers. These results are essentially owed to the context of the study: a developing country where the state plays a determining role in the economic life and where the private sector cannot assure alone the good functioning of the economy.

In reality, the presence of the state stays until our days predominate in the most Tunisian firms in spite of the privatization program started since several years. The public powers constitute the authority of regimentation and thus define a set of measures to repressive 
character or purifying in order to discipline managers.

Finally, larger firms, however, are also found to better use free cash flow at their disposal, which is inconsistent with the idea that larger firms generate greater agency costs. Alternatively, given the definition used to calculate free cash flows, it could be that larger firms are relatively less profitable which leaves lower cash flows available following debt financing and income distributions. Our finding confirms the result of Henry (2010).

\subsection{Capital structure determinants}

In accordance with our anticipations the coefficient associated to the variable free cash flow is positive and statistically significant to the level of $5 \%$ in the equation of the debt. Our results show that firms with more severe overinvestment problem have higher levels of leverage. Jensen (1986) suggests that in case of low growth opportunities agency costs of free cash flow rise, so, debt should be issued. Indeed, probability of overinvestment by managers is reduced as firms commit to use future free cash flows for paying out investors. Our hypothesis $\mathrm{H}_{1}$ (b) concerning the relation between the leverage and the free cash flow is therefore confirmed.

Our findings show that the coefficient associated to the weight of immobilizations in the total of asset has a negative and significant sign at the 0.05 level. Our hypothesis $\mathrm{H}_{3}$ (b) concerning the relation between the leverage and the structure of asset is therefore confirmed. Our finding corroborates the empirical study of Hosono (2003) concerning the capital structure determinants of Manufacturing Firms in Japan.

Otherwise, this finding seems to confirm the pecking order theory that suggests that firms with few tangible assets will be most sensitive to the information asymmetry. So, they will use the debt that is an external financing vehicle less sensitive to information asymmetry that stocks (Harris and Raviv 1991). Indeed, in Tunisia the major part of the firm debt banking. According to Rajan and Zingales (1995), the tangibility of assets must take less importance in countries bank-dominated. Another explanation more specific to the Tunisian firms, and relative to the real value of fixed assets which is appreciated (and the appreciation has not been reflected in accounts of the firms), will be able to be to the origin of this relation.

Besides, profitability is strongly negatively related with leverage. This negative correlation demonstrates that the highly profitable firms have need of less external funds. It support for the pecking order theory by Myers and Majluf (1984). It is also consistent with Huang and Song (2006) for listed firms in China and Sheikh and Wang (2010) for firms listed on the stock market of Karachi. An explanation consists in considering that the profitable Tunisian firms are more incited to finance their activities by the financial markets and no by the debt. This finding also comes in support of the hypothesis that stipulates that managers choose the internal financing resource in the first place in order to control agency costs resulting from external financing.

Finally, it is to signal that no conclusion can be made as for the effect of the size, of the variation of the risk, of the firm growth and of the tax on the leverage from the moment the relative coefficients are non significant. In the same way, the relative coefficient to the 
variable «industry» is always non significant. In other words, the industrial firms don't appear nor more leveraged nor less leveraged than the non industrial firms. This finding comes in support of those found by Drobetz and Fix (2005) for the Swiss firms and Kim and al., (2006) for the non financial listed firms in Korea.

\section{Conclusion and implication}

The purpose of this paper is to explore the implications of the free cash flow hypothesis concerning the disciplinary role of ownership structure and capital structure policy in an emerging stock exchange such as that of Tunisia. We adopted the three stage least square simultaneous model approach basis of a sample composed of 35 non financial listed firms during the period going from 1999 to 2008. Our results show that firms with more severe overinvestment problem have higher levels of leverage and the impact of the leverage on the free cash flow is significantly negative, consistent with the free cash flow hypothesis. Moreover, managerial ownership and state ownership has a negative effect on the level of free cash flow. Hence, in the Tunisian firms, the overinvestment problem can be mitigated by issuing debt and by increasing managerial and state ownership. However, the ownership concentration increases the risk of the free cash flow. Though, the impact of institutional ownership on free cash flow is not significant. Finally, we should signal that the estimated model doesn't integrate all corporate governance mechanisms. We mention the dividend policy and the board of directors that constitute also the main systems of control omitted in our study.

\section{References}

Agrawal A. and Knoeber C.R. (1996). Firm Performance and Mechanisms to Control Agency Problems between Managers and Shareholders. Journal of Financial and Quantitative Analysis 31 (3). 377-397.

Al-Deehani. T.M and Al-Saad.K.M. (2007). Ownership Structure and Its Relationship with Capital Structure: An Empirical Study on the Companies Listed in the Kuwait Stock Exchange. Arab Journal of Administrative Sciences 14 (2).

Al-khouri. R. (2006). Corporate governance and firm's value in emerging markets: the case of Jordan. Advances in Financial Economics 11, 31-50.

Andrés P., López F.J., and Rodríguez J.A. (2005). Financial Decisions and Growth Opportunities: A Spanish Firms Panel Data Analysis. Applied Financial Economics 15(6), 391- 407.

Aoun. D and Heshmati. A. (2006). The Causal Relationship between Capital Structure and Cost of Capital: Evidence from ICT Companies Listed at NASDAQ. The Ratio Institute Working Papers 87.

Bennett. M. and Donnelly. R. (1993). The Determinants of Capital Structure: Some UK Evidence. British Accounting Review. 25 1, 43-59.

Berger P. Ofek E. and Yermach D. (1997). Managerial Entrenchment and Capital Structure Decisions. Journal of Finance 52. (4), 1411-1438.

Billett. M.T. et al. (2007). Growth Opportunities and the Choice of Leverage, Debt Maturity, and Covenants. The Journal of Finance LXII (2), 697-730. 
Booth. L. Aivazian. V. Demirguc-Kunt. A. and Maksimovic. V. (2001). Capital structure in developing countries. Journal of Finance 56, 87-130

Brickley J.. Lease R. and Smith C. (1988). Ownership structure and voting on an takeover amendments. Journal of financial economics 20, 267-291.

Buettner. Overesch. Schreiber. Wamser and George. (2009). Taxation and capital structure choice: Evidence from a panel of German multinationals. Economics Letters. 105 (3), 309-311

Cadoret. B. Martin. H and Tanguy. (2004). Économétrie appliquée: méthodes, applications. corrigés. De Boeck Université.452 pages

Cai K. R. Fairchild. and Guney. Y. (2008). Debt maturity structure of Chinese companies. Pacific-Basin Finance Journal 16, 268-297.

Chang. C. Lee. Alice C.and Lee. Cheng F. (2009). Determinants of capital structure choice: A structural equation modeling approach. The Quarterly Review of Economics and Finance 49, 197-213.

Chen. J. J. (2004). Determinants of capital structure of Chinese-listed companies. Journal of Business Research 57, 1341 - 1351.

Chen. X. and Yur-Austin. J. (2007). Re-measuring agency costs: The effectiveness of blockholders. The Quarterly Review of Economics and Finance 47(5), 588-601.

Ciceksever. B. J. Kale. and H. Ryan. (2006). Corporate governance, debt, and activist institutions. Georgia State University working paper.

De Jong A. and Dijk R.V. (2007). Determinants of Leverage and Agency Problems: A Regression Approach with Survey Data. European Journal of Finance 13(6), 565-593.

De Jong.A. Kabir.T.T and Nguyen. R. (2008). Capital structure around the world: The roles of firm- and country-specific determinants. Journal of Banking and Finance 32(9), 1954-1969

De Miguel. A. and Pindado J. (2001). Determinants of capital structure: new evidence from Spanish panel data. Journal of Corporate Finance 7, 77-99

Del Brio E.. Perote J. and Pindado J. (2003). Measuring the Impact of Corporate Investment Announcements on Share Prices: the Spanish Experience. Journal of Business. Finance and Accounting 30,715-747.

Delcoure N. (2007). The determinants of capital structure in transitional economies. International Review of Economics and Finance. 16, 400-415.

Demsetz.H. (1983). The structure of ownership and the theory of the firm. Journal of Law and Economics 2 (June), 375-390.

Demsetz.H. and Lehn K. (1985). The structure of corporate ownership: causes and consequences. Journal of Political Economy 93(6), 1155-1177.

Demsetz.H. and Vilallonga B. (2001). Ownership structure and corporate performance. Journal of Corporate Finance 7(3), 209-233.

D'Mello.R. and Miranda.M. (2010). Long-term debt and overinvestment agency problem. Journal of Banking and Finance 34, 324-335

Doukas. J.A. C. Kim. and C. Pantzalis. (2005). Security Analysis, Agency Costs and Firm Characteristics. International Review of Financial Analysis 14(5), 493-507 
Driffield.N.L. and Pal .S. (2007). How does ownership structure affect capital structure and firm performance? Recent evidence from East Asia. Economics of Transition 15 (3), 535-573 Drobetz W and Fix R. (2005). What are the determinants of the capital structure? Some evidence for Switzerland . Revue Suisse d'Economie et de statistique 1(mars), 71-114.

Duggal R. and Millar J.A. (1999). Institutional ownership and firm performance: The case of bidder returns. Journal of Corporate Finance 5.

Ezeoha. A.E. (2008). Firm size and corporate financial leverage choice in a developing economy. The Journal of Risk Finance. 94. 351-364.

Faccio M. and Lasfer M.A. (2002). Institutional Shareholders and Corporate Governance: The Case of U.K. Pension Funds In: J. McCahery. P. Moerland. T. Raaijmakers. and L. Renneboog. eds. Corporate Governance Regimes: Convergence and Diversity. Oxford University Press

Fattouh. Scaramozzino and Harris. (2005). Capital structure in South Korea: a quantile regression approach. Journal of Development Economics 761, 231-250.

Flannery. M.J. and K.P. Rangan. (2006). Partial adjustment toward target capital structures. Journal of Financial Economics79(3) 469-506

Fluck. Z. D. Holtz-Eakin. and H.S. Rosen. (2000). Where does the money come from? The financing of small entrepreneurial enterprises, New York University Working paper.

Frank. M. andGoyal. V. (2000). Testing the pecking order theory of capital structure. Journal of Financial Economics 67( 2), 217-248.

Garvey G.T. and G. Hanka. (1999). Capital structure and corporate control: the effect of anti-takeover statutes on firm leverage. Journal of finance 54 (2), 519-546.

Ghosh. S. (2007). Leverage, managerial monitoring and firm valuation: A simultaneous equation approach. Research in Business 61, 84-98.

Graham. J.R. and Tucker. A.L. (2006). Tax shelters and corporate debt policy. Journal of Financial Economics 81, 563-594.

Grossman. S. J. and O. D. Hart. (1982). Corporate Financial Structure and Managerial Incentives. In: The Economics of Information and Uncertainty. Ed. Par J. J. McCall. Chicago: The University of Chicago Press, 123-155.

Gul F.A.. Jaggi B. (1999). An analysis of joint effects of investment opportunity set. free cash flow and size on corporate debt policy . Review of Quantitative Finance and Accounting 12(4), 371-381.

Halov N..and Heider.F. (2005). Capital Structure, asymmetric information and risk. EFA 2004 MAASTRICHT, 1-56.

Harris M. and Raviv.A. (1991). The theory of capital structure. Journal of Finance 46(1), 297-355

Henry. (2010). Agency costs, ownership structure and corporate governance compliance: A private contracting perspective. Pacific-Basin Finance Journal 181, 24-46.

Hosono. (2003). Growth Opportunities. Collateral and Debt Structure: The Case of the Japanese Machine Manufacturing Firms. Japan and the World Economy 15(3), 275-97.

Hovakimian. (2006). Are Observed Capital Structures Determined by Equity Market Timing? Journal of Financial and Quantitative Analysis 41 (1), 221-243. 
Huang. G. and F.M. Song. (2006). The Determinants of Capital Structure: Evidence from China. China Economic Review 17, 14-36.

Hudson M.R. Parrino R. and Starks L. (1998). International monitoring mechanisms and CEO turnover: A long term perspective. Unpublished manuscript University of Pennsylvania. Imam. M and Malik. M. (2007). Firm Performance and Corporate Governance through Ownership structure. International Review of Business Research Papers 3(4), 88-110

Jensen. M. and Meckling. W. (1976). Theory of the firm: Managerial behavior, agency costs and capital structure. Journal of Financial Economics 3, 305-360

Jensen. M.. (1986). Agency costs of free cash flow, corporate finance and takeovers. American Economic Review 76, 323-329

Karadeniz. S. Y. Kandir. M. Balcilar and Y. B. Onal. (2009). Determinants of capital structure: evidence from Turkish lodging companies. International Journal of Contemporary Hospitality Management 215, 594-609

Kim. H.. Heshmati. A.. and Aoun. D. (2006). Dynamics of capital structure: the case of Korean listed manufacturing companies. Asian Economic Journal 203, 275-302.

Kremp E. and Stoss E. (2001). L'endettement des entreprises industrielles françaises et allemandes : des élutions distinctes malgré des déterminants proches. Economie et Statistique $\mathrm{n}^{\circ} 1 / 2$.

La Rocca. La Rocca and Cariol. (2007). Overinvestment and Underinvestment Problems: Determining Factors: Consequences and Solutions. Corporate Ownership and Control 5 (1), 79-95.

Lang L.H.P.. Ofek O. and Stulz R.M. (1996). Leverage, Investment. and Firm Growth . Journal of Financial Economics 40, 3-29.

McKnight and Weir. (2009). Agency costs, corporate governance mechanisms and ownership structure in large UK publicly quoted companies: A panel data analysis. The Quarterly Review of Economics and Finance 49, 139-158

Miller. Merton H. (1977). Debt and Taxes. Journal of Finance, 261-275.

Miller. Merton H. (1991). Leverage. Journal of Finance 46 (2), 479-488.

Modigliani F. and M. Miller. (1958). The cost of capital, corporation finance and the theory of investment. American Economic Review, 261-297.

Modigliani F. and M. Miller. (1963). Corporate Income Taxes and the cost of capital. American Economic Review, 433-443.

Myers. Stewart C. (1977). Determinants of Corporate Borrowing. Journal of Financial Economics 5(2), 147-175.

N. Eriotis. V. Dimitrios and V. N. Zoe. How firm characteristics affect capital structure: an empirical study. Managerial Finance 335, 321-331.

Nekhili M.. Wali A. and Chebbi D. (2009). Free cash flow, gouvernance et politique financière des entreprises françaises. Finance Contrôle Stratégie 12 (1), 5-31.

Pao. (2008). A comparison of neural network and multiple regression analysis in modeling capital structure, Expert Systems with Applications 35, 720-727

Pindado J. and De la Torre C. (2005). A Complementary Aroach to the Financial and Strategy Views of Capital Structure: Theory and Evidence from the Ownership Structure. $S S R N$ working paper. 
Poulain-Rehm T. (2005). L'impact de l'affectation du free cash flow sur la création de valeur actionnariale : le cas de la politique d'endettement et de dividendes des entreprises françaises cotées . Revue Finance. Contrôle. Stratégie 8 (4), 205-238.

Pound J. (1988). Proxy contests and the efficiency of shareholder oversight. Journal of financial economics 20, 237-266.

Rajan R.G. and Zingales. L. (1995). What do we know about capital structure? Some evidence from international data, Journal of Finance 50(5), 1421-1460

Sheikh and Wang. (2010). Financing Behavior of Textile Firms in Pakistan. International Journal of Innovation. Management and Technology 1 (2), 130-135.

Shyam-Sunder L. and S.C Myers. (1999). Testing static tradeoff against pecking order models of capital structure. Journal of Financial Economics 51, 219-244

Singh M. and Davidson III W.N. (2003). Agency costs, ownership structure and corporate governance mechanism. Journal of Banking and Finance 27, 793-816.

Solh. M. (2000). Fonds de pension et politique d'investissement à long terme des entreprises. thèse de doctorat en sciences de gestion. Université de Paris X Nanterre

Stulz. (1990). Managerial Discretion and Optimal Financing Policies. Journal of Financial Economics 26, 3-27

Taggart. (1977). A model of corporate financing decisions. Journal of Finance 32, 1467-1484.

Tang. C.H. and Jang. S.C. (2007). Revisit to the determinants of capital structure: A comparison between lodging firms and software firms. International Journal of Hospitality Management 261, 175-187.

Titman and Wessels. (1988). The determinants of capital structure choice. Journal of Finance 43, 1-19.

Vilasuso. J. and Minkler. A. (2001). Agency costs., asset specificity, and the capital structure of the firm. Journal of Economic Behavior and Organization 441, 55-69.

Wiwattanakantang and Yupana. (1999). An empirical study on the determinants of the capital structure of Thai firms. Pacific-Basin Finance Journal 73(4), 371-403.

$\mathrm{Wu}$ and Yue. (2009). Corporate tax, capital structure. and the accessibility of bank loans: Evidence from China. Journal of Banking and Finance 33(1), 30-38

$\mathrm{Wu}$ L. (2004). The Impact of Ownership Structure on Debt Financing of Japanese Firms with the Agency Cost of Free cash flow. EFMA Meetings Paper.

Zhang. H and Li. S. (2008). The Impact of Capital Structure on Agency Costs: Evidence from UK Public Companies. Proceedings of the 16th Annual Conference on Pacific Basin Finance Economics Accounting Management PBFEAM Conference

Zou.H. and J. Z. Xiao. (2006). The financing behavior of listed Chinese firms. The British Accounting Review 38, 239-258.

Zwiebel J. (1996). Dynamic Capital Structure under Managerial Entrenchment. American Economic Review 86 (5), 1197-1215. 